\title{
Fourth industrial revolution and the paradigm change in engineering education
}

\author{
Rustem Sakhapov ${ }^{1, *}$ and Svetlana Absalyamova ${ }^{2}$ \\ ${ }^{1}$ Kazan State University of Architecture and Engineering, Kazan, Russia \\ ${ }^{2}$ Kazan Federal University, Kazan, Russia
}

\begin{abstract}
The article discusses the main features of the fourth industrial revolution and its impact on the transformation of the labor market and the transition to a new paradigm of education. Authors analyze new requirements for the graduates competence and modern world educational trends. Much attention is paid to strengthening of the project nature of education, blurring the distinction between traditional technical and humanitarian education. Moreover, the authors examine the shift of engineering work with its basic elements - invention, engineering, and design in the field of technical engineering in the area of economic, financial, social, cultural, anthropological design. This requires the creation of new interdisciplinary courses, the revision of the classical approaches to engineering and humanitarian education. The article explores the personalization of the educational trajectories, artificial intelligence as a teacher, e-learning technologies and simulators, information educational environment.
\end{abstract}

\section{Introduction}

The 46th economic forum in Davos, Switzerland, held in January 2016 had the Fourth Industrial revolution as a main topic of the agenda.

"The First Industrial Revolution used water and steam power to mechanize production. The Second used electric power to create mass production. The Third used electronics and information technology to automate production. Now a Fourth Industrial Revolution is building on the Third, the digital revolution that has been occurring since the middle of the last century. It is characterized by a fusion of technologies that is blurring the lines between the physical, digital, and biological spheres," said the forum Chairman Professor Klaus Schwab [10].

All industrial revolutions had dramatically changed the content of labor and labor relations [1], had caused the demand for different specialties and professions and had brought new requirements to education system and training. The first revolution shifted labor from manual to machine and led to the emergence of new working professions.

The second industrial revolution caused rapid development of high-tech industries engineering, aviation, chemical industry etc. This had raised the demand for science and

\footnotetext{
* Corresponding author: rustem@sakhapov.ru
} 
engineering and increased their prestige. Many countries have created a multilevel system of personnel training for the industry. Factories (employers) became actively involved in educational process, creating workforce training centers and sending the most talented young workers to higher schools. During this period, the natural sciences and engineering professions significantly prevailed over humanitarian and socio-economic. Mass industrial production has been in need of a large number of standardized specialists with default qualifications and national systems of education has been active in developing educational standards and strictly adhere to them in the process of highly qualified personnel training.

The third Industrial revolution was based on the transition to telecommunication technologies, their integration into production and educational process [5].

Table 1 shows the impact of industrial revolutions on educational paradigm changes.

Table 1. Change of technological cycles and educational paradigms

\begin{tabular}{|c|c|c|c|}
\hline $\begin{array}{l}\text { Period, } \\
\text { centuries }\end{array}$ & Revolution & Industrial changes & Educational changes \\
\hline XVIII - IXX & $\begin{array}{l}\text { 1st industrial } \\
\text { revolution }\end{array}$ & $\begin{array}{l}\text { Invention of steam } \\
\text { engine, the Transition } \\
\text { from manual labor to } \\
\text { machine }\end{array}$ & $\begin{array}{c}\text { Emergence of work } \\
\text { specializations, } \\
\text { establishment of } \\
\text { professional schools, } \\
\text { development of universities }\end{array}$ \\
\hline $\begin{array}{c}\text { IXX - } \\
\text { beginning of } \\
\text { XX }\end{array}$ & $\begin{array}{c}\text { 2nd } \\
\text { industrial } \\
\text { revolution }\end{array}$ & $\begin{array}{c}\text { Transition to } \\
\text { electricity, } \\
\text { development of } \\
\text { transport, } \\
\text { communications, } \\
\text { development of high- } \\
\text { tech industries }\end{array}$ & $\begin{array}{l}\text { Development of multilevel } \\
\text { training system for industry, } \\
\text { standardization of education, } \\
\text { prestige growth of } \\
\text { engineering education }\end{array}$ \\
\hline $\begin{array}{c}2^{\text {nd }} \text { half of XX } \\
\text {-beginning } \\
\text { XXI }\end{array}$ & $\begin{array}{c}\text { 3rd } \\
\text { industrial } \\
\text { revolution }\end{array}$ & $\begin{array}{c}\text { Transition to } \\
\text { telecommunication } \\
\text { technologies, } \\
\text { automation of } \\
\text { production, rapid } \\
\text { development of } \\
\text { services }\end{array}$ & $\begin{array}{l}\text { Integration and globalization } \\
\text { of education, development } \\
\text { of academic mobility, } \\
\text { transition to the international } \\
\text { educational standards, } \\
\text { increase in training } \\
\text { specialists for services }\end{array}$ \\
\hline $\begin{array}{l}\text { Beginning } \\
\text { XXI }\end{array}$ & $\begin{array}{l}\text { 4th industrial } \\
\text { revolution }\end{array}$ & $\begin{array}{l}\text { The Internet of things, } \\
\text { integration of "cyber- } \\
\text { physical systems", or } \\
\text { CPS, in production } \\
\text { processes, neuronet }\end{array}$ & $\begin{array}{l}\text { Individualization and } \\
\text { virtualization of education, } \\
\text { strengthening of project and } \\
\text { multidisciplinary nature of } \\
\text { engineering education, } \\
\text { the development of } \\
\text { interactive educational } \\
\text { resources }\end{array}$ \\
\hline
\end{tabular}

It increased the productivity and reduced the demand for blue-collar workers directly involved in production. The existing system of secondary and specialized secondary education and training of working specialties was destroyed. Engineering education started to gradually phase out, and the nature of motivation and realistic goals of students (for degree, with no intention to work) has changed. Then the demand for economic and management education for the development of the city economy and services sector increased. The development of education in the 2000s was built on the ideas of integration and globalization 
and the principles of learning throughout life, mobility and recognition of educational documents worldwide.

Despite the fact that the Third Industrial revolution hasn't spread all around the world yet, experts say that today there is a new "revolutionary situation", which is reflected in the concept of "Industry 4.0".

\section{Transformation of educational policy in terms of the fourth industrial revolution}

The basis of Industry 4.0 is the concept of the Internet of things. It assumes that each physical object ("thing") has an integrated technology that allows it to interact with other objects. A key driver of the Fourth Industrial revolution is the integration of "cyber-physical systems", CPS, in production processes. This could be a disaster for the lots of specializations and professions and could cause a fundamental change in the nature of education and the organization of the educational process. The industry is not simply being supplanted by the service sector, but there is a change of industrial production. Distinctive features of the "other industry" are the intellectual growth and turning innovation into a key factor of competitiveness of enterprises. The "other industry" requires different type of engineering education - a more compact (on the quantity of graduate engineers), clearly oriented on the needs of the emerging industrial clusters and updated content. Standard educational programs are giving place to individual educational trajectories in which people use different deinstitutionalized and institutionalized forms of education. The paradigm is changing from being knowledge and object-centered to practice-oriented, subject-centered and competencebased [9].

The main question that worries the global educational system is "How the process of transformation of the traditional model of education in the era of the Fourth industrial revolution would happen?" The Report "The Future of education: a global agenda" tries to answer this question. The authors claim that "the report examines "the new education" as a system for supporting the educational needs of a person throughout life, in contrast to the socalled "industrial education", which is built on the principles of linearity of the educational process, uniformity of educational content and "packaging" of people in groups for training, mostly by age. The current system of school and University education is built on these principles, having high efficiency in preparing people with standard skills, but having difficulties with the formation of non-standard skills and support of personal development" [3].

Among the technological innovations that could radically change education, we can list the Internet of things, automatic semantic translators, high-level artificial intelligence, 3D printing, biotechnologies, massive brain-computer interfaces etc. The development of braincomputer interfaces and the creation of appropriate network protocols can become the basis of the cognitive revolution in learning and a new generation of Internet, neuronet, that will involve both body and consciousness of people in a single communication. In the near future, educational practices may include biometric devices to track activity and physical characteristics of the student, to correct the methods and speed of learning and to plan individual educational programs.

Textbooks and teachers may gradually lose the position of the main sources of knowledge. Information, which is being updated and widening very fast, tends to be presented in interactive multimedia formats; traditional libraries are being replaced by knowledge databases in media formats [9]. The role of teachers in the near future may be passed to virtual tutors. The role of gaming environments and augmented reality in educational activities is growing. According to forecasts, games and teamwork will become the dominant forms of education and social life by 2035. Artificial intelligence might become 
a mentor ("Diamond primer") and a partner in knowledge and training will occur in neuronet groups. Diploma of graduation from educational institutions, scientific journals and standards of citation, textbooks, the existing system of intellectual property management may die [3].

Another direction of education development is strengthening of its project nature, blurring the distinction between traditional technical and humanitarian education. Under the influence of the new industrial revolution some expect the offset of the engineering activities with its basic elements (invention, engineering, and design) in the field of technical engineering to the area of economic, financial, social, cultural, anthropological design. This requires the creation of new interdisciplinary courses, the revision of the classical approaches to engineering and humanitarian education.

In the case of deep socio-economic changes, universities tend to play not the role of suppliers of qualified specialists for work in certain sectors of the economy, but the role of "development institutions" - sites, which will create new activities, new business opportunities, new forms of social activity [3].

Further education development will go in the direction of its division. The most accessible type of education for wide range of population will become mass trainings with the use of new technological solutions (educational fast food), such as personalization of educational trajectories, the artificial intelligence as a teacher, e-learning technologies and simulators, information educational environment. Expensive high-intensity "live" education, based on personal interaction with highly qualified teachers and collective creative work, the formation and development of teams, will become more and more elitist, which will increase social inequality of the population. As a consequence, it will have premium nature - and in most cases will be organized not as a long collaborative learning, but as short intensive sessions. The content of this training will focus on the development of complex interdisciplinary competencies associated with creative thinking and supportive psycho-physical "spirit" [11].

In such circumstances, the student cannot be a passive participant of the educational process, and the fact of receiving a diploma does not guarantee employment, if the required competence is not formed at the desired level. A new model of education, where the line between classroom and independent work disappears, suggests the continuous availability of a tutor via interactive learning resources and, in the future, a learning artificial intelligence system. Massive open online courses are mode of competitive training, where only focused and independent activity of the pupil determines the efficiency and effectiveness of the process.

The expansion of the applications of modern education widens nowadays. It is necessary:

- for high labor mobility for life;

- to fully participate in the activities of production structures, which become heterarchic and network;

- for full participation in the life and activities of the various communities;

- for consumption of today's complex and "smart" products and services;

- to build one's own individuality.

One of the key changes on the educational market was the appearance of new global players focused on information and communication technologies that actively promote the idea of "technological learning". Higher education now faces a new competition - the international online universities and massive online courses which is able to remotely train a number of students, inaccessible to conventional educational institutions [6]. The first online course on Machine Learning from Stanford in 2011 was attended by 100 thousand students and its author, Dr. Andrew Ng founded the largest company on the massive open online courses - Coursera in 2012. Today, the project Coursera operates with 16 well-known universities, such as Stanford, Princeton University, University of Michigan, University of California Berkley, University of Pennsylvania. The composition of courses has expanded 
considerably: now it is not only computer science and enterpreneurship, but also medicine, history, sociology, economics, mathematics.

There is a new transnational market outside the education system, which can replace the traditional educational system and introduce new standards rather quick. So, Asian universities rapidly occupy new educational niches, redistributing financial flows. Key players realize that education is a sector, which rotates billions of dollars, and those who enter distance-learning programs first, will get the chance to capture this huge market.

The text above confirms the statement of the famous American economist E. Toffler $[7,8]$ that in the conditions of information society, development of traditional views about quality of life significantly changed, and it more depends on the level of consumption of information products and services, their availability.

\section{Conclusions}

The extent and depth of the actual changes permit us to speak about the formation of "cognitive society", which could be a totally different social organism in comparison to the existing society. Currently, education can be seen as a struggle between social conservatism, social pragmatism and social progress.

Social conservatism is trying to maintain social memory and best educational standards. Public pragmatism uses education as a tool to help solve current societal challenges. Social progress sees education as "the area of breakthrough into the future".

Thus, occurring under the influence of the Fourth industrial revolution social and industrial transformations define new trends of development of modern education. The emergence of new forms of organization of production put forward new requirements for competencies of graduates of educational institutions, changing the meaning and content of the education.

\section{References}

1. S. G. Absalyamova, T. B. Absalyamov, Mediterranean Journal of Social Sciences 6, 227-231 (2015)

2. P. A. Bataykin, A. S. Khasanova, V. V. Shlychkov, A. R. Toumashev, M. V. Toumasheva, Journal of Applied Economic Sciences 11, 521-531 (2016)

3. The future of education: a global agenda http://www.edu2035.org/pdf/GEF.Agenda_ru.pdf (accessed 20.09.2018).

4. V.S. Efimov, A.V. Lapteva, University management: practice and analysis 3(85), 6-21 (2013)

5. Rifkin J., The Third Industrial Revolution: How Lateral Power Is Transforming Energy, the Economy, and the World / Translation from English, Alpina non-fiction, Moscow, 2014.

6. R.L. Sakhapov, T.B. Absalyamov, News of the Samara science center of Russian academy of science 17 (2-4), 891-895 (2015)

7. A. Toffler, Intellectual capital: New source of organization wealth/ Translation from English, "AST Publishing house", Moscow.

8. A. Toffler, Revolutionary Wealth (2006) Knopf ISBN 0-375-40174-1.

9. Foresight «Education 2030». http://www.slideshare.net/ASI-12/2030-14471230.

10. https://www.weforum.org. (accessed 20.09.2018). 
11. N.A. Yastreb, Psychology, sociology \& pedagogy 11 (2014) URL: http://psychology.snauka.ru/2014/11/3911 (accessed 20.09.2018). 